BENHA VETERINARY MEDICAL JOURNAL, VOL. 30, No. 1:192-198, MARCH, 2016

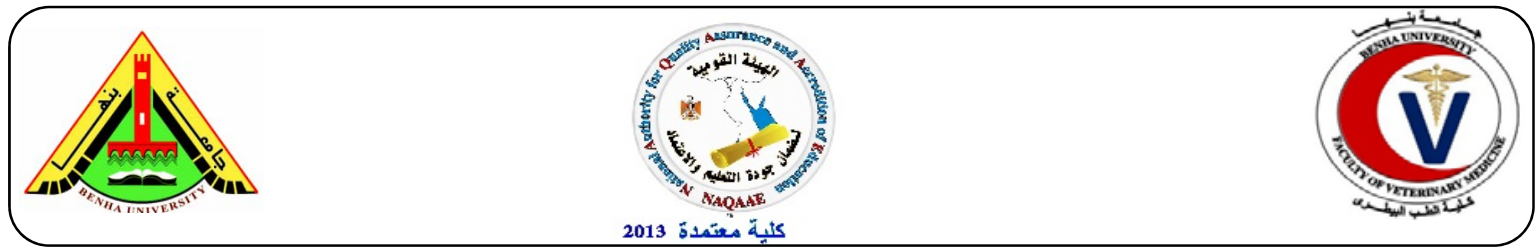

\title{
The effects of dietary prebiotic on phagocytic activity of innate immunity in Oreochromis niloticus
}

\author{
${ }^{1}$ Ashraf A. Abd El Tawab; ${ }^{2}$ Ahmed M. Amaar; ${ }^{3}$ Osama Abd El-Rahman Saleh ; ${ }^{1}$ Fatma Ibrahem \\ Abd-Allah El-Hofy and ${ }^{3}$ Heba Ahmed Tolba \\ ${ }^{1}$ Bacteriology, Immunology and Mycology Department Faculty of Veterinary Medicine, Benha \\ Universityl, ${ }^{2}$ Bacteriology, Immunology and Mycology Department Faculty of Veterinary Medicine, \\ Zagazig University, and ${ }^{3}$ Central Lab for Aquaculture Research, Egypt.
}

\section{A B S T R A C T}

The objectives of this study, effects of prebiotic $\beta$ polo on innate immunity of Oreochromis niloticus (O.niloticus) and increase resist against disease. A total number of 180 Nile-tilapia fish (O. niloticus), were divided into four equal groups; the first one was served as control fed on basal non-treated diet. The second group fed on diet supplemented with $1.5 \mathrm{ml}$ prebiotic $\beta$ polo $/ \mathrm{kg}$ basal fish diet, the third group fed on diet supplemented with $1 \mathrm{ml}$ prebiotic $\beta$ polo $/ \mathrm{kg}$ basal fish diet, and the fourth group fed on diet supplemented with $0.5 \mathrm{ml}$ prebiotic $\beta$ polo $/ \mathrm{kg}$ basal fish diet for 40 days. The results showed that, significant increase in phagocytic activity test and total leucocyte count (TLC) levels. The percent level of protection among the three treated groups after challenge infection using Aeromonus sobria Aer. sobria $\left(0.5 \mathrm{ml}\right.$ of culture suspension of pathogen containing $10^{7}$ bacteria $\left.\mathrm{ml}^{-1}\right)$ was higher than control and the highest record was in the group received $1.5 \mathrm{ml}$ prebiotic $\beta$ polo $/ \mathrm{kg}$ basal fish diet. The results of the present study support the use of $1.5 \mathrm{ml}$ prebiotic $\beta$ polo $/ \mathrm{kg}$ basal fish diet as fish immunostimulants.

Keywords: Prebiotic, Phagocytosis, Aeromonus sobria

(http://www.bvmj.bu.edu.eg)

(BVMJ-30(1): 192-198, 2016)

\section{INTRODUCTION}

$\mathrm{F}$ ish are considered the cheapest source of animal protein of high nutritive value especially in developing countries including Egypt. It also a source of essential minerals, vitamins, fat, iodine, fluorine and special amounts of cobalt, magnesium, phosphorous, iron and copper (Gram and Huss, 2000 and Krizek et al., 2004). Intensification of fish farming in aquaculture often leads to deterioration of water quality and this condition makes the cultured organism vulnerable to diseases. Aquaculture faces serious problems due to various adverse effects of antibiotics such as accumulation in the tissue, immune suppression and emergence of resistant microorganisms (Nayak, 2010). Thus stimulation of the innate immune system by dietary supplement is a suitable approach for fortification of an organism against diseases (Trichet, 2010). Among various immunostimulants, the immune modulatory effects of yeast glucan have already been established in several fish species, The beta-glucans are polysaccharides derived from the cell wall of yeast and fungi. Administration of dietary glucan enhanced growth performance of various fish species (Meena et al., 2012). Moreover, dietary glucan also improved the resistance against bacterial pathogens in several cultured fish species (Jeney G. and Anderson DP., 1997, Misra et al., 2006). The objectives of this study, effects of prebiotic $\beta$ polo on innate 
immunity of O.niloticus and increase resist against disease.

\section{MATERIALS AND METHODS}

\subsection{Source of tested fish}

Apparently healthy Nile tilapia (Oreochromus niloticus) of 25-35 g/fish weight and 9.5-12 cm length were collected from the ponds of the Central Laboratory for Aquaculture Research. Total numbers of 180 fish were kept in previously prepared 12 full glass aquaria $(70 \times 60 \times 50 \mathrm{~cm})$, and these aquaria were used for holding the steps of feeding experiment throughout the period of the investigation (40 days). The aquaria were supplied with chlorine free water. The average of water temperature was $25^{\circ} \mathrm{C} \pm 1{ }^{\circ} \mathrm{C}$ and the oxygen was adjusted for continuous aeration by using electrical air pumping compressors (RINA, Italy). Fish were acclimated under the laboratory conditions in indoor tanks for 2 weeks for experimental study.

\subsection{Experimental diets of tested fish:}

The tested fish were divided into four groups, each group, in three replicates, each 15 fish. The first group (T1), fish were fed with control diet (basal non-treated diet). The second group (T2), was treated with 1.5 $\mathrm{ml}$ prebiotic $\beta$ polo $/ \mathrm{kg}$ standard fish diets). While, the third group (T3), m was treated with $1.0 \mathrm{ml}$ prebiotic $\beta$ polo $/ \mathrm{kg}$ standard fish diets. The fourth group (T4), was treated with $0.5 \mathrm{ml}$ prebiotic $\beta$ polo $/ \mathrm{kg}$ standard fish diet). The fish was fed three times per day for 40 days at a daily rate $3 \%$ of body weight. The water of the aquaria was changed daily. The fish were weighted after 10,20, 30 and 40 days from the beginning of the feeding experiment

\subsection{Microbial strains:}

Aeromonus sobria for challenge test was kindly supplied by fish Health and management department, Central Laboratory for Aquaculture Research, Abbassa. Candida albicans was kindly supplied by fish Health and management department, Central Laboratory for Aquaculture Research. It was used in a concentration of $5 \times 10^{6} \mathrm{CFU} / \mathrm{ml}$ to determine the phagocytic activity according to the method described by (Wilinksons, 1977).

\subsection{Blood and serum sampling:}

Blood samples were collected before and after feeding experiment (every 10 days for 40 days) from the caudal blood vessels of fish, by using syringes previously rinsed in EDTA (15 unit $/ \mathrm{ml}$ ) for the evaluation of TLC according to Feldman et al. (2000) by Natt and Herrick solution and phagocytic activity according to the method described by (Wilinksons, 1977) .

Separation of white blood cells: White blood cells separation was carried out according to the method described by Andreson et al., (1978). Preparation of C. albicans for determining the phagocytic activity according to the method described by (Wilinksons, 1977):

Measuring of phagocytic activity according to the method described by (Wilinksons, 1977):

Phagocytic percentage was calculated according to this formula:

$$
\begin{gathered}
\text { Phagocytic } \%=\frac{\text { Number of phagocytic cells engulfing No. of labeled } C \text {. albicans }}{\text { Total number of phagocytic cells }} \\
\text { P.I. }=\frac{\text { Total number of } C \text {. albicans in } 100 \text { phagocytic cells }}{100}
\end{gathered}
$$




\subsection{Challenge test:}

The treated as well as the control fish groups were challenged by $\mathrm{I} / \mathrm{P}$ injection of $0.5 \mathrm{ml} 10^{7}$ cells of $24 \mathrm{hrs}$. cultures of virulent Aeromonas sobria at the ends of 40 days' post feed experiment. Fish were observed for two weeks post challenge for mortality rate and the relative level of protection (RLP) calculated according to the equestion of (Newan and Majnarichsm1982)

RLP $=1$ - [percentage of treated mortality/ percentage of control mortality] x 100 .

\subsection{Statistical analysis: According to Murray (1975) by one way ANOVA}

\section{RESULT}

\subsection{Total leucocytic count}

Effect of prebiotic $\beta$ polo on total leucocytic count (TLC): Total leucocytic count(TLC) showed significant increase in $\mathrm{T} 2$ and $\mathrm{T} 3$ in comparison with $\mathrm{T}_{1}$ all the experiment period and showed no significant change in $\mathrm{T} 4$ in comparison with $\mathrm{T}_{1}$ all the experiment period, as shown in (Table 1). The highest value of TLC obtained at T2 $\left(19.95 \times 10^{3} \pm 9.0\right)$ after 40 days in comparison with $\mathrm{T}_{1}$ and the lowest value of TLC obtained at T4 $\left(15.43 \times 10^{3} \pm 1.0\right)$ after10 days in comparison with $\mathrm{T}_{1}$ (Table 1$)$.

\subsection{Phagocytic activity (effect of prebiotic Bpolo on phagocytic activity):}

\subsubsection{Effect of prebiotic Bpolo on phagocytic percentage: -}

Cell phagocytic percentage or index was determined in $O$. niloticus fish each 10 days for the experiment period after treatment with different concentration prebiotic $\beta$ polo. Peripheral blood was collected and phagocytic assay was done as described in the fish. White blood cells phagocytic activity was determined in O.niloticus fish post feeding on prebiotic $\beta$ polo. Results of table 2 showed, after 10 days and 20 days, Cell phagocytic precentage showed significant increase in $\mathrm{T} 2, \mathrm{~T} 3$ and $\mathrm{T} 4$ in comparison with $\mathrm{T}_{1}$. But, after 30 days and 40 days showed significant increasein $\mathrm{T} 2$ and $\mathrm{T} 3$ in comparison with $\mathrm{T}_{1}$ and no significant change obtained inT4 in comparison with $\mathrm{T}_{1}$.

The highest value of phagocytic activity obtained at T2 $(95.66 \% \pm 3.480)$ after 40 days in comparison with $\mathrm{T}_{1}$ (photo1) and the lowest value of phagocytic activity obtained at $\mathrm{T} 4(64.56 \% \pm 2.919)$ after10 days in comparison with $\mathrm{T}_{1}$.

\subsubsection{Effect of prebiotic Bpolo on phagocytic index:-}

Phagocytic index was done to determine the cells capacity to engulf more microbes. Results of table 3 showed, the phagocytic index showed significant increase in $\mathrm{T} 2$ and $\mathrm{T} 3$ and no significant difference in $\mathrm{T} 4$ in comparison with $T_{1}$ all the experiment period. The highest value of PI obtained at $\mathrm{T} 2(25.50 \pm 1.89)$ after 40 days in comparison with $\mathrm{T}_{1}$ (photo1) and the lowest value of PI obtained at $\mathrm{T} 4(3.33 \pm 0.88)$ after10 days in comparison with $\mathrm{T}_{1}$.

\subsection{Mortality rate and Relative level of protection in treated $O$. niloticus after challenge with Aeromonas sobria}

O. niloticus after challenge with Aeromonas sobria showed the highest mortality in $\mathrm{T}_{1}$ than other treatments that received prebiotic $\beta$ polo supplemented diet and no mortality after challenge with Aeromonas sobria obtained relative level of protection against Aeromonas sobria in $\mathrm{T}_{2}$ was higher than in other treatments ( and decreased in the other treatments compared to control (T1) showed in table (4). 
Table (1). Effect of prebiotic ßpolo supplemented diet on Total leucocytic count (TLC) in O. niloticus for forty days of feeding experiment.

\begin{tabular}{l|l|l|l|l}
\hline Treatments & days & 20 days & 30 days & 40 days \\
\hline T1 & $15.72 \times 10^{3} \pm 0.0 \mathrm{~b}$ & $15.63 \times 10^{3} \pm 8.0 \mathrm{~b}$ & $15.65 \times 10^{3} \pm 2.0 \mathrm{~b}$ & $14.10 \times 10^{3} \pm 1.0 \mathrm{~b}$ \\
T2 & $19.22 \times 10^{3} \pm 3.0 \mathrm{a}$ & $19.65 \times 10^{3} \pm 2.0 \mathrm{a}$ & $19.82 \times 10^{3} \pm 2.0 \mathrm{a}$ & $19.95 \times 10^{3} \pm 9.0 \mathrm{a}$ \\
T3 & $17.25 \times 10^{3} \pm 8.0 \mathrm{a}$ & $17.82 \times 10^{3} \pm 3.0 \mathrm{a}$ & $17.93 \times 10^{3} \pm 1.0 \mathrm{a}$ & $18.05 \times 10^{3} \pm 2.0 \mathrm{a}$ \\
T4 & $15.43 \times 10^{3} \pm 1.0 \mathrm{~b}$ & $16.50 \times 10^{3} \pm 6.0 \mathrm{~b}$ & $15.16 \times 10^{3} \pm 1 \mathrm{~b}$ & $14.50 \times 10^{3} \pm 8.0 \mathrm{~b}$ \\
\hline
\end{tabular}

Means carrying different superscripts are at $(p \leq 0.05)$. The values were given as means \pm S.E. of three replicates. Means with different letters within column differ significantly, $P \leq 0.05$, Means with same letters within column non-differ significantly, $P \leq 0.05$ (a- c).

Table (2): Phagocytic percentage in $O$. niloticus phagocytic cells treated with three different concentrations of prebiotic $\beta$ polo for forty days.

\begin{tabular}{lllll}
\hline Treatment & 10 days & 20 days & 30 days & 40 days \\
\hline T1 & $31.66 \% \pm 0.81 \mathrm{~b}$ & $41.00 \% \pm 0.57 \mathrm{~b}$ & $53.00 \% \pm 1.52 \mathrm{~b}$ & $60.66 \% \pm 0.33 \mathrm{~b}$ \\
T2 & $89.66 \% \pm 0.47 \mathrm{a}$ & $91.66 \% \pm 2.33 \mathrm{a}$ & $90.33 \% \pm 0.892 \mathrm{a}$ & $95.66 \% \pm 3.48 \mathrm{a}$ \\
T3 & $87.90 \% \pm 0.09 \mathrm{a}$ & $90.76 \% \pm 1.85 \mathrm{a}$ & $82.00 \% \pm 0.736 \mathrm{a}$ & $82.33 \% \pm 0.69 \mathrm{a}$ \\
T4 & $69.00 \% \pm 0.92 \mathrm{a}$ & $75.60 \% \pm 0.43 \mathrm{a}$ & $64.56 \% \pm 2.919 \mathrm{~b}$ & $71.00 \% \pm 0.50 \mathrm{~b}$ \\
\hline
\end{tabular}

Means carrying different superscripts are at $(p \leq 0.05)$. The values were given as means $( \pm$ S.E. $)$ of three replicates. Means with different letters within column differ significantly, $P \leq 0.05$, Means with same letters within column non-differ significantly, $P \leq 0.05$ (a-c).

Table (3): Phagocytic index in O. niloticus phagocytic cell treated with three different concentrations of prebiotic $\beta$ polo for forty days

\begin{tabular}{lllll}
\hline Treatments & 10 days & 20 days & 30 days & 40 days \\
\hline T1 & $7.36 \pm 0.409 \mathrm{~b}$ & $7.03 \pm 0.731 \mathrm{~b}$ & $5.90 \pm 0.58 \mathrm{~b}$ & $5.33 \pm 0.88 \mathrm{~b}$ \\
$\mathrm{~T} 2$ & $21.43 \pm 0.72 \mathrm{a}$ & $16.86 \pm 1.57 \mathrm{a}$ & $21.03 \pm 2.67 \mathrm{a}$ & $25.50 \pm 1.89 \mathrm{a}$ \\
$\mathrm{T} 3$ & $11.83 \pm 1.013 \mathrm{a}$ & $10.76 \pm 1.29 \mathrm{a}$ & $16.88 \pm 1.05 \mathrm{a}$ & $13.11 \pm 0.67 \mathrm{a}$ \\
T4 & $5.11 \pm 0.485 \mathrm{~b}$ & $3.66 \pm 1.45 \mathrm{~b}$ & $3.33 \pm 0.88 \mathrm{~b}$ & $4.00 \pm 1.52 \mathrm{~b}$
\end{tabular}

Means carrying different superscripts are at $(p \leq 0.05)$. The values were given as means $( \pm$ S.E. $)$ of three replicates. Means with different letters within column differ significantly, $P \leq 0.05$, Means with same letters within column non-differ significantly, $P \leq 0.05$ (a-c).

Table (4): Mortality rate and Relative level of protection in treated $O$. niloticus after challenge with Aeromonas sobria.

\begin{tabular}{lll}
\hline \multirow{2}{*}{ treatments } & \multicolumn{2}{l}{ Aeromonas sabia } \\
\cline { 2 - 3 } & Mortality\% & RLP \\
\hline $\mathrm{T}_{1}$ & 46.66 & 0 \\
$\mathrm{~T}_{2}$ & 0 & 100 \\
$\mathrm{~T}_{3}$ & 6.66 & 85 \\
$\mathrm{~T}_{4}$ & 10 & 78 \\
\hline
\end{tabular}




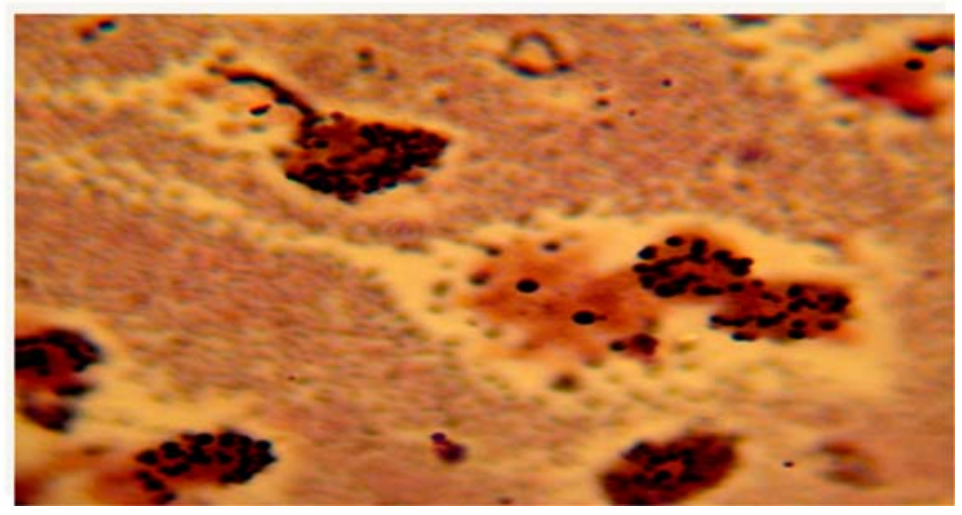

Photo 1: Yeast cells engulfment by phagocytic cells isolated from $O$. niloticus blood, feeding by prebiotic $\beta$ polo supplemented diet for 40 days of feeding experiment.

\section{DISCUSION}

Administration of dietary glucan is a beneficial tool for stimulation of immune system of fish and fortification of immune response (Soltanian et al., 2009). Concerning the non-specific immune stimulation in $O$. niloticus fish groups received diets supplemented with prebiotic $\beta$ polo. These could be attributed to the components of prebiotic $\beta$ polo ( $\beta$-gluca), b1,3/1,6-Glucans bind specifically to a "receptor molecule" on the surface of phagocytes (Engstadand et al., 1994). b1,3/1,6-glucans have the same basic biological effect, When the receptor is engaged by $b-1,3 / 1,6$-glucan, the cells become more active in engulfing, killing and digesting bacteria and at the same time they secrete signal molecules (cytokines) which stimulate the formation of new white blood cells. And also, have the specific immune mechanisms in addition to nonspecific defense, the activated phagocytes produce cytokines which also, activate antibody-producing white blood cells (Band T-cells). Therefore, b-1,3/1,6-glucan enhances also the efficacy of vaccines. Due to the very basic mode of action of b$1,3 / 1,6$-glucans, products in this category affect a number of different biological processes, including not only disease resistance, but also growth (Raa J., 2000). our study agree with Jessus et al. (2002) who reported that phagocytic ratio and phagocytic index rose to their highest level on $42 \mathrm{hrs}$. after feeding with diet containing $250 \mathrm{mg}$ of Beta-glucan $/ \mathrm{kg}$ diet. It was clear that high non-specific immunity was developed as manifested by increased number of leucocytic count as well as increase in the percentage of phagocytosis and phagocitic index. The results indicated that TLC, the percentage of Phagocytosis and Phagocytic index in O. niloticus in (T2) was the best result, followed by $O$. niloticus in (T3) in comparison to O. niloticus in (T1).The present result agree with Misra et al. ( 2006), Yancui Zhao et al. (2011) and Sirimanapong W et al(2015) who PI and PC\% increase significantly by Glucan.And Selvaraj et al. (2006) ,Jamal K. A. et al.(2014),Agouz, H. M. and Anwer, W. (2011). And agree Rudabeh Rufchaie and Seyed Hossein Hoseinifar(2014) and (Cuesta et al., 2004)who on the same line of the present study where stated glucan increase significant the TLC .The result of (table 4) mortality rate and relative level of protection of o.niloticus after $\mathrm{i} / \mathrm{p}$ with pathogenic Aeromonas sobria agree with Ai, Q., K. et al. (2007) who reported that multiple injections of -glucan enhance the immune response and disease resistance against opportunistic pathogens Aeromonas hydrophila \& Edwardsiellata. and agree with . also supported by The $\beta$-1,3-glucans of certain yeasts have been successfully used as immunostimulants to enhance the defense potential of fish and shellfish 
against bacterial and viral infection and agree with (Abdel-Tawab et al., 2008 and Misra et al., 2006).

\section{CONCLUSION}

Prebiotic $\beta$-polo at 1.5 and $1 \mathrm{ml} / \mathrm{kg}$ fish diets have enhance phagocyte activity of innate immunity of (O. niloticus) in form of increasing phagocytic capacity, TLC and also increased resistance against Aeromonas sobria.

\section{REFERENCES}

Abdel-Tawab, M., Abdel-Rahman, A.M., Ismael, N.E.M. 2008. Evaluation of commercial live bakers' yeast, Saccharomyces cerevisiae as a growth and immunity promoterfor Fry Nile tilapia, Oreochromis niloticus (L.) challengedin situ with Aeromonas hydrophila. Aquaculture, 280: 185189.

Agouz, H.M., Anwer, W. 2011. Effect of Biogen and Myco-Ad on the growth performance of common carp Cyprinus carpio fed a mycotoxin contaminated aqua feed. J. Fish. Aqua. Sci., 6: 334-345.

Ai, Q., Mai, K., Zhang, L., Tan, B., Zhang, W., Xu, W. 2007. Effects of dietary $\beta-1,3$ glucan on innate immune response of large yellowcroaker, Pseudosciaena crocea. Fish Shellfish Immunol 22: 394-402.

Andresen, R., Burgger, W., Gadd, S.S., Lohr, G.W., Athkins, R.C. 1978. Activation of human monocytesderived macrophages culture in Teflon: Response to interferongamma during terminal maturation in vitro. Immunobiol., 177: 186-198.

Cuesta, A., Meseguer, J., Esteban, M. 2004. Total serum immunoglobulin $\mathrm{M}$ levels are affected by immunomodulatorsin sea bream (Sparus aurata L.). veterinary immunology and immunopathology, 101: 203-210.
Feldman, B.F., Zikl, J.G., Jain, V.C. 2000. Schlam's Veterinary Hematology. $5^{\text {th }}$ ed. Lippincott Williams and Wilkins. Canada, pp. 1145-46.

Gram, L., Huss, D. 2000. Fresh and processed fish and shell fish (ch 12 (eds) lund, B.M; T.C. Baird-parker and G.W. Gould. The microbiology safety and quality of food. Fish and Shellfish Immunol., 15 (9): 663-968.

Jamal, K., Al-faragi, E., qbal, S., Najem, D., Sanaa, A., Mustafa, A. 2014. Effect of $\beta$-glucan on behavioral, biochemical and hematological parameters against toxicity of copper sulfate in common carp Cyprinus carpio L. The Iraqi Journal of Veterinary Medicine, 38(2): 128-173.

Jeney, G., Anderson, D.P. 1997. Enhanced immune response and protection in rainbow trout to Aeromonas salmonicida bacterin following prior immersion and some innate immune responses in zebrafish (Danio rerio). Fish \& Shellfish Immunology, 27: 369-373.

Engstad, R.E., Robertsen, B., Frivold, E. 1994. Yeast glucan induces increase in lysozyme and complementmediated haemolytic activity in Atlantic salmon blood. Fish Shellfish Immunol., 2: 287-297.

Jessus, O., Alberto, C., Alejandro, R.M., Angeles, E., Jose, M. 2002. Oral administration of yeas, Sacchar omyces cerevisiae, enhances the celluler innate immune response of gillhead seabream, Sparus aurata L. J. Veterinary immunology and immunopathology 85: 41-50.

Krizek, M., Vacha, F., Vorlova, L., Lukasova, J. 2004. Biogenic amines in vacuum-Packed and non- vacuumpacked flesh of carp (Crpinus carpioi) stored at different temperatures, Food Chemistry 88: 185-191.

Meena, D., Das, P., Kumar, S., Mandal, S., Prusty, A., Singh, S., Akhtar, M., Behera, B., Kumar, K., Pal, A. 2012. 
Beta-glucan: an ideal immunostimulant in aquaculture (a re-view). Fish Physiology and Biochemistry, 1-27.

Misra, C.K., Das, B.K., Mukherjee, S.C., Phalguni, P. 2006. Effect of long term administration of dietary Beta-glucan on immunity, growth and survival of Labeo rohita fingerling, Aquaculture 255(1-4): 82-94.

Murray, R.S.1975. "probability and statistics", McGRAW- Hill Book Company

Nayak, S.K. 2010.Probiotics and immunity: A fish perspec-tive. Fish \& Shellfish Immunology, 29: 2-14.

Newan, G., Majnarichsm, H. 1982. Direct immersion vaccination of juvenile rainbow trout salmo (Onchorynchus kisutch) with a Yersinia ruckeri bacterium. Jour. Fish DIS., 5: 338341.

Raa, J. 2000. The use of immune-stimulants in fish and shellfish feeds. In: Cruz Suárez, L.E., Ricque-Marie, D., Tapia-Salazar, M., Olvera-Novoa, M.A. y Civera-Cerecedo, R., (Eds.). Avances en Nutrición Acuícola V. Memorias del V Simposium Internacional deNutrición Acuícola. 19-22 Noviembre, 2000. Mérida, Yucatán, Mexico.

Rudabeh, R., Seyed, H. H. 2014.Effect of dietary commercial yeast glucan on innate immune response, hematological parameters, intestinal microbiota and growth performance of white fish (Rutilis Fristi) fry, Croatian Journal of Fisheries, 72: 156-163.
Selvaraj, V., Sampath, K ., Sekar V. 2006. Adjuvant and immunostimulatory effects of $\beta$-glucan administration in combination with lipopolysaccharide enhances survival and some immune parameters in carp challenged with Aeromonas hydrophila. Vet Immunol Immunopathol 114: 15-24.

Sirimanapong,W., Adams,A., Oi,E.L., Gre en,D.M., Nguyen,D.K., Browdy,C.L. , Collt, B., Thompson, K.D.2015.The effects of feeding immuno stimulant $\beta$-glucan on the immune response of Pangasianodon hypophthalmus. J.Fish Shellfish Immunol.45(2): 35766.

Soltanian, S., Stuyven, E., Cox, E., Sorgeloos, P., Bossier, P. 2009. Betaglucans as immunostimulant in vertebrates and invertebrates. Critical reviews in microbiology, 35: 109-138.

Trichet, V. V. 2010. Nutrition and immunity: an update. Aquaculture Research, 41: 356-372.

Wilinksons, P.C. 1977.Techniques of Qulincal immune edited by thlpson, R.A, publication. P. 201. USA.

Yancui, Z., Hongming, M., Wenbing, Z., Qinghui, A., Kangsen, M., Wei, X., Xiaojie, W., Zhiguo, L. 2011. Effects of dietary? -glucan, mannan oligosaccharide and their combinations on growth performance, immunity and resistance against Vibrio splendidus of sea cucumber, Apostichopus japonicus. Fish \& shellfish immunology 31(2): 303 